\title{
DIVERSIDADE RACIAL E EDUCAÇÃO FÍSICA ESCOLAR NA REVISTA BRASILEIRA DE CIÊNCIAS DO ESPORTE (1979-2013)
}

\author{
Leydiane Vitória Sales, Universidade Federal de Mato Grosso - UFMT, Mato Grosso \\ - Brasil \\ Neil Franco Pereira de Almeida, Universidade Federal de Mato Grosso - UFMT, \\ Mato Grosso - Brasil
}

\section{RESUMO}

Este estudo tem como objetivo analisar e discutir de que forma a temática da diversidade racial e Educação Física escolar é contextualizada na Revista Brasileira de Ciências do Esporte (RBCE) no período de 1979 a 2013 e verificar se com a criação dos Parâmetros Curriculares Nacionais (PCN) e a homologação da lei federal 10.639/2003 alterações foram provocadas nos aspectos quantitativos e qualitativos da inserção da temática racial na RBCE. Trata-se de uma pesquisa indireta e de abordagem quantiqualitativa. Foram encontrados na RBCE vinte e cinco produções enfocando a temática diversidade racial e Educação Física, dos quais oito destacam o contexto escolar. Evidenciou-se que essa temática permeia esse periódico timidamente e que a criação dos PCN e a homologação da lei 10.639/2003 não provocaram indícios de alterações nos aspectos quantitativos e qualitativos da inserção da relação diversidade racial e Educação Física escolar na RBCE.

Palavras-Chave: Lei 10.639/003; Diversidade racial; Educação Física escolar; RBCE.

\section{RACIAL DIVERSITY AND SCHOOL PHYSICAL EDUCATION IN THE BRAZILIANMAGAZINE OF SPORTSCIENCES (1979-2013)}

\begin{abstract}
This study aims to analyze and discuss how the issue of racial diversity and Physical Education is contextualized in the Brazilian Magazine of Sports Science (BMSS) from 1979 to 2013 and check with the creation of the National Curriculum Parameters (NCP) and the approval of federal law 10.639/2003 caused quantitative and qualitative changes in the insertion of the race issue in BMSS aspects. This is an indirect research and quantitative and qualitative approach. Were found in BMSS twenty-five productions focusing on the theme racial diversity and Physical Education. eight of which highlight the school context. Was evidenced that this theme permeates this journal shyly and that the creation of the NCP and the approval of the law 10.639/2003 caused no indications of changes in the quantitative and qualitative aspects of the relationship of insertion and racial diversity and Physical Education in BMSS.
\end{abstract}

Key-Words: Law 10.639/003; Racial diversity; School Physical Education; RBCE.

Conexões: revista da Faculdade de Educação Física da UNICAMP, Campinas, v. 13, n. 1, p. 129-161, jan./mar. 2015.

ISSN: $1983-9030$ 


\section{DIVERSIDAD RACIAL Y EDUCACIÓN FÍSICA ESCOLAR EN LA REVISTA BRASILEÑA DE CIENCIAS DEL DEPORTE (1979-2013)}

\section{RESUMEN}

Este estudio analiza y discute de que forma la temática de la diversidad racial y Educación Física escolar es contextualizada en la Revista Brasileña de Ciencias del Deporte (RBCE) en el periodo de 1979 a 2013 y verificar si con la creación de los Parámetros Curriculares Nacionales (PCN) y la homologación de la ley federal 10.639/2003 provocó alteraciones en los aspectos cuantitativos y cualitativos de la inserción de la temática racial en la RBCE.

Se trata de una investigación indirecta y de abordaje quanti-cualitativa. Fueron encontrados en la RBCE veinticinco producciones enfocando la temática diversidad racial y Educación Física, de los cuales ocho destacan el contexto escolar. Evidenciou que esa temática permeia ese periódico tímidamente y que la creación de los PCN y la homologación de la ley 10.639/2003 no provocaron indicios de alteraciones en los aspectos cuantitativos y cualitativos de la inserción de la relación diversidad racial y Educación Física escolar.

Palabras-Clave: Ley 10.639/2003; Diversidad racial; Educación Física escolar; RBCE. 


\section{INTRODUÇÃO}

Este artigo tem como objetivo analisar e discutir de que forma a temática da diversidade racial e Educação Física escolar é contextualizada na Revista Brasileira de Ciências do Esporte (RBCE) no período de 1979 a 2013. Da mesma forma, verificar se com a criação dos Parâmetros Curriculares Nacionais (PCN) e a homologação da Lei Federal $10.639 / 2003^{1}$ alterações foram provocadas nos aspectos quantitativos e qualitativos da inserção da temática racial na RBCE. Com isso, foram traçados os seguintes objetivos específicos: realizar levantamento bibliográfico sobre produções científicas relacionadas à Educação Física e diversidade racial; identificar como as discussões sobre a temática racial na escola é abordada nos documentos oficiais e qual seu viés para a disciplina Educação Física; levantamento dos artigos científicos relacionadas à Educação Física e diversidade racial disponíveis no portal eletrônico da RBCE; correlação das fontes bibliográficas e documentais com os dados construídos a partir do levantamento realizado na $\mathrm{RBCE}$, verificando em que dimensão esses estudos se relacionam ao contexto escolar.

A RBCE é editada trimestralmente pelo Colégio Brasileiro de Ciências do Esporte $(\mathrm{CBCE})^{1}$ sendo significativa para a área do conhecimento da Educação Física, conectada a importantes sociedades científicas, tal como a Sociedade Brasileira para o Progresso da Ciência (SBPC). O CBCE foi fundado no ano de 1978. Consiste de uma instituição científica formada por pesquisadores/as da área de Educação Física e Ciências do Esporte. Esta entidade é representada por secretarias estaduais e grupos de trabalhos temáticos, sendo coordenados por uma diretoria nacional. O CBCE promove a cada dois anos um evento nacional intitulado Congresso Brasileiro de Ciências do Esporte (CONBRACE); entre esses encontros bienais são realizados eventos regionais e estaduais.

\footnotetext{
${ }^{1}$ Também conhecida como Lei Ben-Hur, em consideração ao autor do projeto deputado federal do Mato Grosso, BenHur Ferreira, militante do movimento negro. ${ }^{6}$

Conexões: revista da Faculdade de Educação Física da UNICAMP, Campinas, v. 13, n. 1, p. 129-161, jan./mar. 2015.

ISSN: $1983-9030$
} 
Um ano após o surgimento do CBCE e do CONBRACE foi criada a $\mathrm{RBCE}^{2}$, com sua primeira publicação em1979. Neste periódico emergiu a necessidade de se investigar o fenômeno do esporte num contexto mais abrangente e científico, tendo como objetivo incrementar os estudos acerca do crescimento profissional em torno do conhecimento da Ciência dos Esportes. ${ }^{2}$

\section{METODOLOGIA}

Metodologicamente, este estudo trata-se de uma pesquisa indireta e de abordagem quanti-qualitativa. Para Mattos, Rossetto Júnior e Blecher ${ }^{3}$ “[...] a pesquisa indireta caracteriza-se pela utilização de informações, conhecimentos e dados já coletados por outras pessoas e demonstrados por diversas formas, como documentos, leis, projetos, desenhos, livros artigos e jornais, etc.[...]". Dentro dessa vertente, o "estado da arte" ou "estado do conhecimento" foi o procedimento utilizado na construção e análise do material investigado, qual seja, artigos que discutam a temática da diversidade racial na RBCE. Segundo Norma Ferreira ${ }^{4}$ essa perspectiva de investigação é definida como de caráter bibliográfico e assumem o desafio de mapear e discutir produções acadêmicas em determinado campo do conhecimento com o intuito de responder que aspectos e dimensões, épocas e lugares, formas e condições, se constituem esses campos, podendo realizar essa construção através da análise de variadas fontes, tais como: dissertações, teses, publicações em periódicos e comunicações em anais de congressos e de seminários.

Também são reconhecidas por realizarem uma metodologia de caráter inventariante e descritivo da produção acadêmica e científica sobre o tema que busca investigar, à luz de categorias e facetas que se caracterizam enquanto tais em cada trabalho e no conjunto deles, sob os quais o fenômeno passa a ser analisado. ${ }^{4: 257}$

Na pesquisa, a quantificação dos dados foi aspecto necessário para solucionarmos parte dos objetivos traçados, contudo, o aspecto qualitativo foi predominante. A abordagem qualitativa busca na explicação da dinâmica das relações sociais a compreensão e explicação de significados, valores e atitudes que compõem os fenômenos sociais. ${ }^{5}$

\footnotetext{
${ }^{2}$ Esta revista é uma das mais conceituadas nacionalmente na área da Educação Física e reconhecida internacionalmente, sendo um periódico classificado pela Coordenação de Aperfeiçoamento de Pessoal de Nível Superior (CAPES) com Qualis B1. ${ }^{1}$

Conexões: revista da Faculdade de Educação Física da UNICAMP, Campinas, v. 13, n. 1, p. 129-161, jan./mar. 2015.

ISSN: $1983-9030$
} 
Com isso, no curso dessa pesquisa, primeiramente, apresentamos uma discussão sobre a relação diversidade racial e Educação Física, destacando, brevemente, seus processos de legislação nacional. Em seguida, nossa ênfase será na descrição e análises dos artigos que enfocam a diversidade racial na RBCE, destacando, por último, aqueles que se destinam especificamente à Educação Física escolar. A finalidade desse percurso é responder a problemática norteadora dessa pesquisa: Diversidade racial e Educação Física escolar são temáticas abordadas na RBCE? Caso positivo, de que forma? Encontraríamos nessas produções indícios e influência da legitimação dos Parâmetros Curriculares Nacionais e da lei 10.639/2003? ${ }^{6}$

Como aspecto de relevância científica, essa pesquisa justifica-se na importância de estimular o debate e a reflexão sobre a temática da diversidade racial que é pouco divulgada e debatida no contexto da Educação Física escolar, já que a Educação Física foi uma das percussoras nas diferenças hierárquicas entre raças na sociedade. Dessa forma, ressaltamos a importância de abordar questões que envolvem a discriminação, preconceito e o racismo presentes no ambiente educacional.

\section{DIVERSIDADE RACIAL E EDUCAÇÃO FÍSICA ESCOLAR}

Segundo o Programa Nacional de Direitos Humanos, o "Racismo é uma ideologia que postula a existência de hierarquia entre os grupos humanos." 7:12 Acredita-se que a palavra racismo se originou do termo italiano razza, que significa grupo de pessoas ou família. O termo árabe rãs pode ser atribuído como outra possível origem da palavra racismo. Para Sant' Ana, outra interpretação seria de sua origem do termo árabe ras, remetendo à descendência ou origem. ${ }^{8}$ Desta forma, o racismo pode vincular-se ao preconceito, discriminação e estereótipos no que se refere às "[...] formas de manifestação de ideologias que defendem a ideia de hierarquia entre pessoas [...]", podendo ser melhor interpretada como "[...] uma opinião preestabelecida, que é imposta pelo meio, época e educação."7:12 Portanto, um fator regulador da relação entre certas pessoas e a sociedade, pautadas na noção reducionista de um fenótipo superior e outro inferior, que atribuiu menor ou maior valor humano. ${ }^{8}$ 
Para Goellner et al. o termo raça ou identidade racial, trata-se de um conceito histórico, social e cultural construído para distinguir grupos de pessoas ou sujeitos baseado nas características biológicas, físicas ou genéticas, sendo utilizado no século XIX apontando o discernimento entre cor da pele: raça branca e negra. ${ }^{9}$ Desta forma, vários/as autores/as salientam que se trata de um conceito estigmatizado ou "destorcido", cuja finalidade é de demarcar a supremacia de dominação e força social na reprodução das desigualdades, valores e atitudes discriminatórias e preconceituosas contra sujeitos e grupos negros. O pressuposto desse conceito não se sustenta sob o aspecto biológico como o cabelo ou cor da pele, mas sim, na questão social permeada por desigualdades identitária. $^{10}$

Ainda em conformidade com estes/as autores/as, o termo raça teve ampliação enquanto conceito estigmatizado durante a II Guerra Mundial quando os nazistas justificavam sua supremacia branca e ariana consideradas por eles como a raça pura, promovendo, com isso, a segregação e dominação da "raça negra". Entretanto, atualmente, para vários pesquisadores/as, quando o termo raça é utilizado em determinado segmento como diversidade/igualdade racial não está ligado à ideologia nazista, pelo contrário, rejeita-se a ideia que se tenha raças superiores e inferiores, aspecto observado por Munanga e Gomes ao ressaltarem que "[...] esse uso tem um sentido social e político, que diz respeito à história da população negra no Brasil e à complexa relação entre raça, racismo, preconceito e discriminação racial."10:175 De acordo com todas essas argumentações, confirma-se que histórica e socialmente o preconceito racial fundamenta-se no aspecto físico e/ou cultural de forma negativa, irradiando por todas as dimensões da sociedade, inclusive, na escola. De acordo com Bozzi et al.

\footnotetext{
No que se relaciona a escola, sabe-se que é muito mais difícil um indivíduo negro entrar e/ou permanecer na mesma do que uma pessoa branca ou, quando isto ocorre, este é geralmente submetido a críticas que o inferioriza de alguma forma. Tal prática na escola humilha e exclui aqueles que são submetidos à ela e assim, marginaliza aqueles que não se encaixam nos padrões impostos. Este fato é comumente observado e, na maioria das vezes, aqueles que deveriam intervir, como professores e pedagogos, não sabem como fazê-lo ou, outras vezes são propagadores deste tipo de atitude, o que reforça e estimula o preconceito ao invés de intervir e combatê-lo..$^{11: 1}$
}

Conexões: revista da Faculdade de Educação Física da UNICAMP, Campinas, v. 13, n. 1, p. 129-161, jan./mar. 2015. ISSN: 1983-9030 
No ambiente escolar essas atitudes, em especial, nas aulas de Educação Física, podem assumir dimensões mais expressivas em razão da prevalência de práticas corporais envolvendo contato físico e maior envolvimento do grupo de alunos/as nas atividades. Falamos, portanto, da evidência do corpo nessas práticas, o que nos remete a afirmativa de Luiz Bozzi et al. que relata que

[...] devido o preconceito ser fruto de padrões estabelecidos pela sociedade, o corpo reflete a principal forma de manifestação deste, sendo que, especialmente na escola, muitos destes pensamentos são manifestados em forma de críticas, exclusões e humilhações. ${ }^{11: 1}$

Relacionado ao contexto histórico da Educação Física que desde seu início visava a eugenia ${ }^{3}$, educadores e médicos viam os exercícios físicos e o esporte como forma de promoção da higienização pessoal. Essa ideia estava entrelaçada com essa disciplina que era responsável pela saúde pública e prevenção de doenças. No aspecto social visava produzir trabalhadores/as mais fortes, obedientes e aptos para o trabalho, aspecto justificado pelo enfoque em disciplinar o corpo e manter a moral. ${ }^{12}$

No decorrer de sua história a Educação Física desenvolveu-se imbricada com as instituições militares, médica e com o intuito de disciplinar o corpo, torná-lo saudável e adestrado. Seguindo essa linha de pensamento, a Educação Física era vista no século XIX, confirmando sua finalidade de modificar os hábitos de higiene e incutir preconceitos de raça nas populações. "Além disso, por decorrência do grande número de escravos negros no país, a educação física esteve associada à educação sexual, na qual as pessoas eram responsabilizadas em manter a 'pureza' e a 'qualidade' da raça branca (eugenia)." $13: 18$

Por meio dessa concepção foi sistematizado o preconceito, a discriminação e o modo de ver a pessoa negra na sociedade. Essa relação entre "corpo saudável" e "higienização da raça branca" foi construída tendo como fundamento, conceitos pragmáticos e equivocados sobre a diferença de raça e/ou cor. Tais diretrizes assumiram grande representatividade na construção do racismo brasileiro difundido no século XIX. ${ }^{14}$

\footnotetext{
${ }^{3}$ A eugenia é uma ação que visa o melhoramento genético da raça humana, utilizando-se para tanto de esterilização de deficientes, exames pré-nupciais e proibição de casamentos consanguíneos. ${ }^{18}$

Conexões: revista da Faculdade de Educação Física da UNICAMP, Campinas, v. 13, n. 1, p. 129-161, jan./mar. 2015.

ISSN: $1983-9030$
} 
Isso mostra a construção do estereótipo sobre o "corpo" e raça tendo em vista que esses aspectos históricos revelam a relação entre a Educação Física e o pensamento dominante naquela época. Essas bases de pensamento favoreciam a difusão da "supremacia branca" aliada à introdução no Brasil dos métodos ginásticos Europeu, principalmente o sueco e o francês em meados dos anos 30 do século XX. Nesse mesmo período, ocorreu a implantação da Educação Física na escola reforçando os ideários do corpo mecânico e disciplinado, e da supremacia branca na aptidão física e na idealização da imagem corporal construída na Grécia Antiga. ${ }^{15}$

Essas concepções científicas procuravam capacitar o indivíduo no propósito de contribuir com a indústria nascente. Este modelo de inspiração militarista e higiênica tinha como objetivo formar uma geração capaz de suportar o combate, a luta, para atuar na guerra e o fortalecimento corporal para o trabalho pesado na indústria. ${ }^{13} \mathrm{Com}$ isso,

[...] a história da disciplina Educação Física aponta para um distanciamento do corpo negro, na medida em que o corpo idealizado pela Educação Física partiu da imagem corporal dos gregos, portanto de um corpo branco. ${ }^{16: 5}$

Atualmente, enquanto espaço das vivências corporais, a Educação Física apresenta subsídios para minimizar esse processo em razão da gama de temas que podem ser inseridos tanto nas aulas práticas como teóricas, construindo, dessa forma, um espaço de discussões sobre a diversidade racial. Dentre as dinâmicas e práticas, tomamos como exemplos a capoeira, manifestação cultural que traz as raízes e ritos de lutas e danças africanas e, também, manifestações rítmicas originárias da cultura negra como o sambade-roda, o maculelê, o jongo, o maracatu, a dança afro, entre outras. ${ }^{17}$ Todos esses elementos compõem-se de conteúdos legitimados oficialmente para serem contextualizados na Educação.

Recentemente a diversidade racial no contexto educacional encontra-se especificadas na lei federal de número 10.639/003, que legitima sobre a inserção da obrigatoriedade de ensinar história e cultura afro-brasileira e africana em todas as fases da Educação

Conexões: revista da Faculdade de Educação Física da UNICAMP, Campinas, v. 13, n. 1, p. 129-161, jan./mar. 2015. 
Básica. Essas discussões já integravam os temas transversais ${ }^{4}$ dos $\mathrm{PCN}$, mais especificamente no volume 10, Pluralidade Cultural, que sugere que esses temas devem perpassar todos os conteúdos das disciplinas da Educação Básica. ${ }^{19}$

A lei $10.639 / 003$ foi uma reivindicação do movimento negro numa proposta de legislação sobre a cultura afro-brasileira e africana para ser levada ao Congresso Nacional que, após um processo acirrado de pressão e contestação sobre os processos de vulnerabilidade envolvendo pessoas negras no cotidiano escolar, foi aprovada. ${ }^{20}$

O conteúdo programático a que se refere o caput deste artigo incluirá o estudo de História da África e dos Africanos, a luta dos negros no Brasil, a cultura negra brasileira e o negro na formação da sociedade nacional, resgatando a contribuição do povo negro nas áreas social, econômica e política pertinentes à História do Brasil. ${ }^{6: 1}$

Uma das questões para que a lei se concretizasse foi por meio de discussões do movimento negro sobre as ações afirmativas que constitui de políticas que lutam contra a discriminação racial, promovendo a igualdade para todos/as na formação educacional, política e social. Essas entidades negras também questionavam sobre o conteúdo superficial que apareciam nos livros didáticos e no currículo escolar da Educação Básica referente à história da África e da cultura afro-brasileira, inviabilizando a história do/a negro/a na Educação. ${ }^{8,}{ }^{10}$ Concluídas essas considerações, destacaremos a seguir a descrição e análises das publicações na RBCE que enfocam a diversidade racial na Educação Física.

\section{DIVERSIDADE RACIAL NA REVISTA BRASILEIRA DE CIÊNCIAS DO ESPORTE (RBCE)}

Conforme nossos objetivos de analisar e discutir de que forma a relação entre diversidade racial e Educação Física escolar são contextualizadas na RBCE desde sua criação em 1979 até o ano de 2013 e verificar se a criação dos PCN e a homologação da lei 10639/2003 provocaram alterações nos aspectos quantitativos e qualitativos da inserção dessas temáticas, realizamos um levantamento das produções científicas

\footnotetext{
${ }^{4}$ Temas transversais são conteúdos específicos como orientação sexual, meio ambiente, pluralidade cultural, ética e saúde que devem ser contemplados por todas as séries e por todas as áreas do conhecimento. Relacionados ao tema pluralidade cultural, insere-se a temática da diversidade racial. ${ }^{19}$
}

Conexões: revista da Faculdade de Educação Física da UNICAMP, Campinas, v. 13, n. 1, p. 129-161, jan./mar. 2015. ISSN: $1983-9030$ 
relacionadas à diversidade racial nos exemplares da RBCE disponíveis no seu portal eletrônico. ${ }^{5}$

Atualmente a RBCE publica trimestralmente suas edições e, em seu $34^{\circ}$ ano de existência, alcançou um total de noventa e oito exemplares publicados, contudo, no portal da RBCE encontram-se disponibilizados para consulta noventa e três exemplares da revista nos quais realizamos nossa coleta de dados. Ao elencar as edições desse periódico disponíveis online, encontramos vinte e cinco trabalhos que abordam a diversidade racial, sendo vinte e um artigos, uma resenha e três resumos. Na Figura 1 detalhamos a quantificação desses dados.

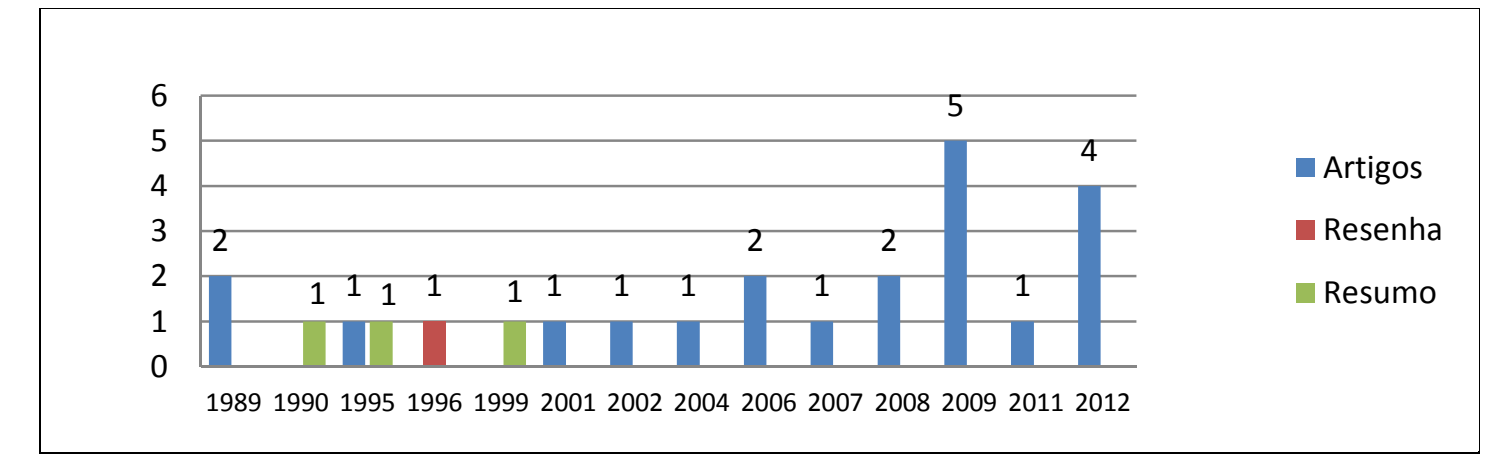

Figura 1: Descrição do número de publicações sobre a diversidade racial e Educação Física escolar na RBCE (1989-2012).

A Figura 1 apresenta o levantamento das publicações sobre diversidade racial na RBCE (1979-2013). Destacamos que somente dez anos após a criação da revista essa temática passou a integrá-la, obedecendo, em seguida, uma frequência de um a dois anos.

Dentre os vinte e cinco exemplares publicados, encontramos contextos variados no campo da diversidade racial e Educação Física, o que nos levou a dividi-los em categorias para a descrição e análise qualitativas, sendo elas: 1-“capoeira” com quinze artigos, uma resenha e dois resumos; 2- "diversidade racial" três artigos e um resumo; 3- "Educação Física escolar e diversidade racial", três artigos. Confira os dados na Figura 2.

\footnotetext{
${ }^{5}$ Ver portal: <www.rbceonline.org.br>.

Conexões: revista da Faculdade de Educação Física da UNICAMP, Campinas, v. 13, n. 1, p. 129-161, jan./mar. 2015.

ISSN: 1983-9030
} 


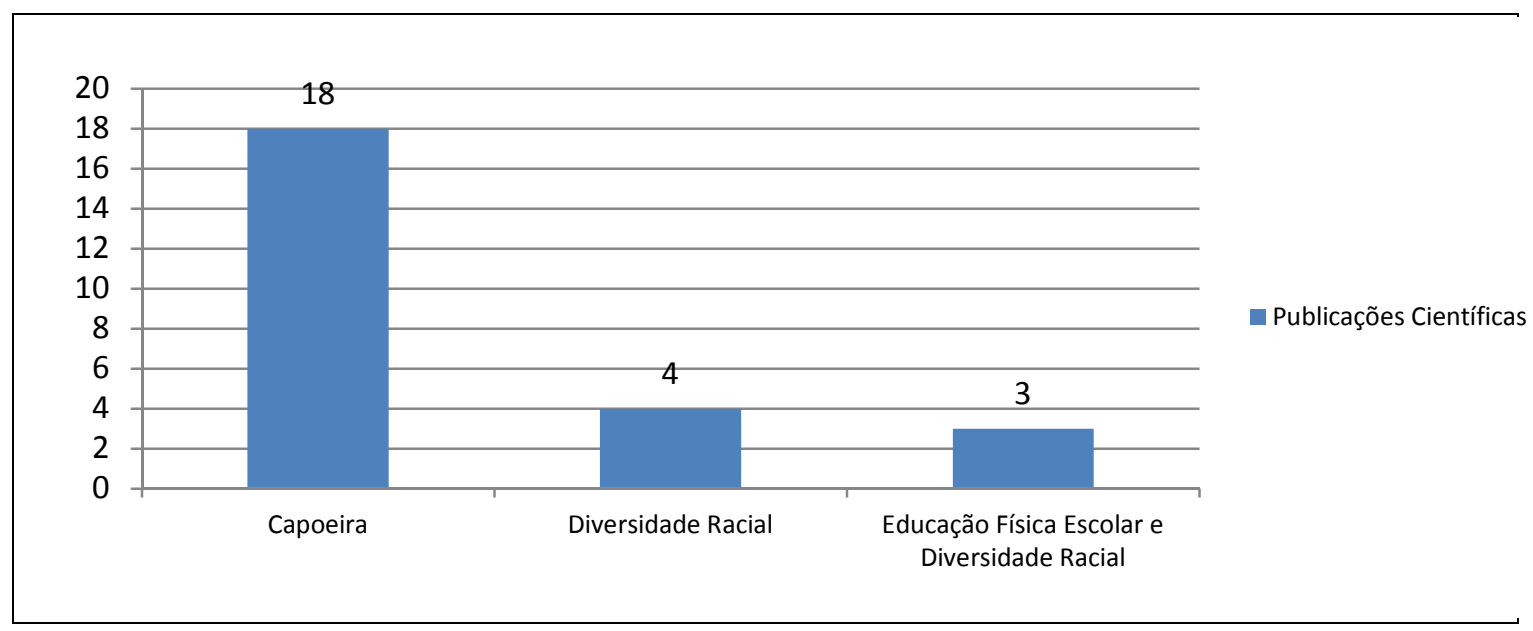

Figura 2: Categorização das vinte e cinco publicações de acordo com seus enfoques.

Como descrito na Figura 2 a capoeira foi a temática predominante nas produções científica com (72\%), seguida da diversidade racial (16\%) e, por último, Educação Física escolar e Diversidade Racial (12\%). Na sequência, apresentaremos uma breve descrição quantitativa e qualitativa dessas categorias, finalizando nossa descrição com uma análise mais apurada dos artigos que enfocam nosso objeto de interesse: diversidade racial e Educação Física escolar.

\section{CAPOEIRA}

Sobre a primeira categoria, capoeira, os textos abrangem diversos contextos, exigindo que criássemos subcategorias para a realização das análises, quais sejam: capoeira e Educação Física escolar, com quatro artigos e um resumo; capoeira, história e política, com quatro produções, três artigos e uma resenha; capoeira e luta/jogo, quatro artigos; capoeira e esporte, duas produções, um artigo e um resumo; capoeira e identidade, dois artigos; capoeira e deficiência, com um artigo. A Figura 3, apresenta esses dados. 


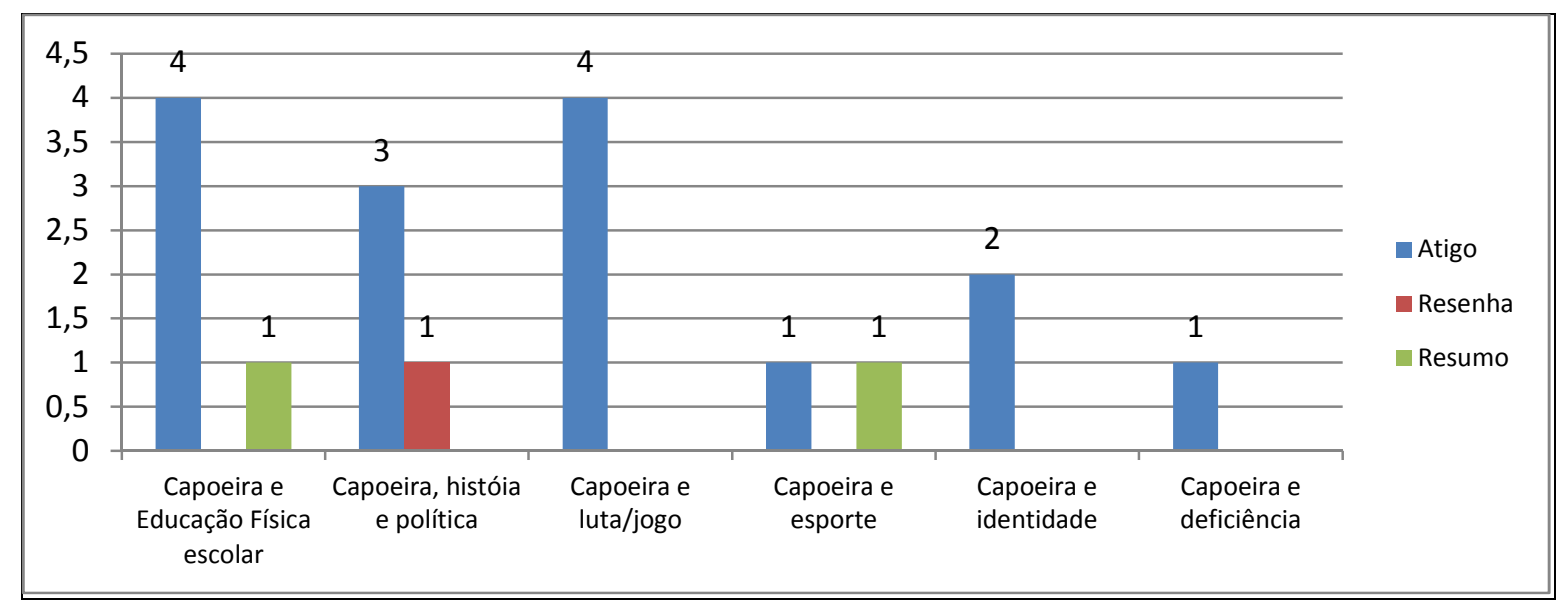

Figura 3: Subcategorização das produções com enfoque na capoeira.

\section{CAPOEIRA: UM BREVE HISTÓRICO}

[...] a capoeira é música, poesia, festa, brincadeira, diversão e, acima de tudo, uma forma de luta, manifestação e expressão de um povo, do oprimido, e do homem em geral, em busca de sobrevivência, liberdade e dignidade. ${ }^{20: 8}$

Iniciamos esse parágrafo referente à capoeira citando a definição dessa manifestação cultural realizada pelo pesquisador Almir das Areais $(1983)^{20}$ que nos brinda com sua analogia sobre essa luta em forma de dança cantada, ritmada e de movimentos precisos das

$\operatorname{artes}_{\text {marciais }}{ }^{6}$ e das artes corporais. Historicamente a capoeira vem se definindo como uma luta/dança/jogo que teve origem a partir das atividades corporais realizadas pelos escravos negros trazidos do continente africano no século XVI para o Brasil colônia, época em que a mão-de-obra escrava era muito utilizada em todas as regiões do país e do mundo. Esses escravos foram trazidos para trabalharem em fazendas de engenho, casas e nas produções de lavouras. A maioria dos/as negros/as era da região do país de Angola e trouxeram consigo a raiz cultural dos costumes e das tradições de sua terra natal, como a dança, o canto e a utilização de instrumentos musicais. Desta forma, no

\footnotetext{
${ }^{6}$ Artes marciais consistem de movimentos/técnicas individuais de defesa e ataque. Foi criada por envolver defesa pessoal sem a utilização de armas, com isso, o nome marciais ou guerreiros surgiu como ferramenta de luta social. ${ }^{29}$ Para Gonçalves e Silva as artes marciais não são apenas práticas corporais, são artes que expressa a luta de emancipação social, da minoria excluída sobre a classe dominante. A capoeira como prática corporal e social se encaixa nesses dois aspectos da luta social/corporal e luta a favor de seus interesses. ${ }^{26}$

Conexões: revista da Faculdade de Educação Física da UNICAMP, Campinas, v. 13, n. 1, p. 129-161, jan./mar. 2015.
}

ISSN: 1983-9030 
Brasil, eles cantavam, dançavam e tocavam os instrumentos como forma de expressar os processos de repressão e injustiça sociais pelos quais eram expostos. ${ }^{21}$

Os senhores das fazendas proibiam a prática de qualquer luta entre escravos, esse fato estimulou os/as negros/as a utilizarem os movimentos das danças africanas para mascarar a luta que continha gestos das artes marciais. Dentre as origens da capoeira, Soares ${ }^{22}$ atribui ao fato de que muitos negros fugiam de seus donos e se escondiam na “capueira”, que significa vegetação, mato, roça abandonada, relacionada à fuga dos/as negros/as para os quilombos. Pode-se dizer que a capoeira através dos ritmos e movimentos das danças africanas serviu para adaptar alguns gestos de luta de autodefesa para enfrentar o inimigo, instigados pela necessidade dos escravos de se protegerem das diversas formas de violências. O corpo era sua arma, com isso, os negros buscavam expressar através da linguagem corporal os sofrimentos ocorridos pela repressão de seus senhores. A prática dessa luta/ ${ }^{7}$ dança/jogo ocorria nas senzalas, terreiros, nos campos de colheita; os campos eram chamados nessa época de capoeirão ou capoeira, com isso surgiu o nome da luta. ${ }^{10}$

No século XVIII a capoeira não era bem vista pela burguesia, sendo considerada uma luta violenta, suja e quem a praticava interpretado como vadio. Era proibida, mas, de certa forma, não tinha nenhuma lei que impedisse de praticá-la em praça pública. Na época da República, sua prática foi considerada crime de acordo com o novo código penal de $1890 .^{21}$

Esse "ritual", a capoeira, é realizado em grupo e formação da roda que é uma característica forte da cultura africana, utiliza-se instrumentos como o berimbau, atabaque, reco-reco, gongo e pandeiro. Dentro da formação do circulo os/as participantes cantam e gingam. Em suma, a capoeira pode ser considerada uma luta pelas características técnicas dos movimentos e execução de golpes que se aproximam das artes marciais em que é realizada por duas pessoas; uma dança por ser uma modalidade em que se utilizam instrumentos musicais e se movimentam conforme a

\footnotetext{
${ }^{7}$ Pautaremos a capoeira como luta/dança/jogo pelas crenças e como forma de linguagem e expressão corporal; a luta em nosso entendimento no campo da capoeira não seria pela questão da força física ou dominação física, mas sim pela liberdade de expressão desses movimentos no trato cultural, do oprimido contra o seu opressor. ${ }^{10}$

Conexões: revista da Faculdade de Educação Física da UNICAMP, Campinas, v. 13, n. 1, p. 129-161, jan./mar. 2015.

ISSN: $1983-9030$
} 
música e cantos ritmados; e um jogo por se tratar de um confronto em que jogadores/as simulam uma disputa, mas que não há vencedores/as. ${ }^{23}$

Há três estilos de capoeira: 1) De Angola: estilo criada na época da escravidão, sua característica é jogar ou dançar em ritmo lento, realizando golpes mais baixo próximo ao chão; 2) Regional: é uma mistura da capoeira de Angola com movimentos de golpes rápidos e secos no ritmo do berimbau e outros instrumentos; 3) Mista ou contemporânea: consiste em uma mescla da capoeira de Angola com a regional. ${ }^{24}$ Mediante esse breve histórico da capoeira, descreveremos as subcategorias que serão analisadas.

\section{CAPOEIRA E EDUCAÇÃO FÍSICA ESCOLAR}

Em nossa busca encontramos cinco publicações que abordam a capoeira e Educação Física escolar, assim como descreve o Quadro 1.

\section{Quadro 1- Publicações sobre capoeira e Educação Física escolar}

\begin{tabular}{lc}
\hline \multicolumn{1}{c}{ Artigos/ autor/a (s) } & Ano \\
\hline 1- Depoimento sobre o ideário Beribazu de capoeira/Mestre Zulu. & 1989 \\
$\begin{array}{l}\text { 2- A escolarização da “vadiação”: a capoeira na Fundação Educacional do Distrito } \\
\text { Federal / José L. Falcão. }\end{array}$ & $1995 a$ \\
$\begin{array}{l}\text { 3- O processo de escolarização da capoeira no Brasil/José L. C. Falcão. } \\
\text { 4- O ensino da capoeira: por uma prática Nagô/Luís V. Castro Junior e José S. }\end{array}$ & 2002 \\
$\begin{array}{l}\text { Sobrinho. } \\
\begin{array}{l}\text { 5- Capoeira nas aulas de educação física: alguns apontamentos sobre os processos } \\
\text { de ensino-aprendizado de professores/Paula C. C. Silva. }\end{array}\end{array}$ & 2011 \\
\hline
\end{tabular}

Esses artigos permeiam suas discussões sobre a inserção da capoeira no âmbito escolar no que se refere à prática pedagógica e formação continuada. Como esses textos abordam a temática central de nossas análises, a relação diversidade racial e Educação Física escolar, detalharemos no último item desse artigo seus objetivos, metodologia e conclusões.

\section{CAPOEIRA, HISTÓRIA E POLÍTICA}

Dos trabalhos publicados na RBCE com enfoque em capoeira, história e política encontramos três produções. O Quadro 2 descreve os periódicos.

\footnotetext{
${ }^{8}$ Trata-se de um resumo de teses e dissertações na edição da RBCE.

Conexões: revista da Faculdade de Educação Física da UNICAMP, Campinas, v. 13, n. 1, p. 129-161, jan./mar. 2015.

ISSN: $1983-9030$
} 
Quadro 2 - Publicações sobre capoeira, história e política

\begin{tabular}{lc}
\hline \multicolumn{1}{c}{ Artigo/autor/a (s) } & Ano \\
\hline 6- O jogo da capoeira: cultura popular no Brasil'/José L. C. Falcão. & 1996 \\
7- Capoeira de Angola: olhares e toques cruzados entre historicidade e ancestralidade/Luís & 2004 \\
V. Castro Junior. & \\
8- Corpos, cultura, paradoxos: observações sobre o jogo de capoeira/ Muleka Mwewa e & 2006 \\
Alexandre F. Vaz & 2006 \\
\hline 9- O jogo da capoeira em jogo/José Luiz C. Falcão & \\
\hline
\end{tabular}

De um modo geral, todos esses artigos se norteiam pelas discussões envolvendo os princípios históricos da capoeira. Falcão ${ }^{25}$ enfoca as relações estabelecidas entre a política e o campo da cultura no Brasil nos anos 30, fazendo uma análise sócio-histórico da capoeira no Brasil durante esse período em que essa modalidade era vista como vadiagem. Além disso, aborda a história da capoeira no país entrelaçada com a Educação Física e as mudanças ocorridas na luta a partir da criação da capoeira regional e a perda de suas características peculiares a que se assemelha a capoeira de Angola. ${ }^{25}$ Mwewa e $\mathrm{Vaz}^{24}$ tecem argumentações mais específicas sobre as atribuições de força, virilidade e bestialização do corpo negro em nossa sociedade, aspecto socialmente enfatizado no imaginário social da relação raça negra e capoeira.

Castro Junior $^{23}$ aborda a ancestralidade da capoeira e as tradições culturais de origem africana como forma de ensinar os valores de respeito e convívio de geração para geração através dessa luta. ${ }^{23}$ Falcão $^{26}$ problematiza sobre o conceito de jogo e sua relação com o capitalismo. Estas produções permeiam também o enfoque da subcategoria "capoeira jogo/luta" que será especificada a seguir.

\section{CAPOEIRA E LUTA/JOGO}

Com enfoque em capoeira e luta/jogo, foram encontrados quatro artigos, descritos no Quadro 3.

\footnotetext{
${ }^{9}$ Trata-se da resenha encontrada na RBCE.

Conexões: revista da Faculdade de Educação Física da UNICAMP, Campinas, v. 13, n. 1, p. 129-161, jan./mar. 2015.

ISSN: 1983-9030
} 
Quadro 3- Publicações sobre capoeira e luta/jogo

\begin{tabular}{lc}
\hline \multicolumn{1}{c}{ Artigo/autor/a (s) } & Ano \\
\hline $\begin{array}{l}\text { 10- Criatividade e clichês no jogo da capoeira: a racionalização do corpo na sociedade } \\
\text { contemporânea/Luiz R. Vieira }\end{array}$ & 1989 \\
$\begin{array}{l}\text { 11- Alguns sentidos e significados da capoeira, da linguagem corporal da Educação } \\
\text { Física/Gilberto O. Santos. }\end{array}$ & 2009 \\
$\begin{array}{l}\text { 12- Ritmo \& rebeldia em jogo: só na luta da capoeira se canta e dança?/Marcelo B. N. } \\
\text { Stoz e José Luís C. Falcão. }\end{array}$ & 2012 \\
13- Dialogia: o corpo e o jogo de significados/Lucas C. D. Silva e Alexandre D. Ferreira. & 2012 \\
\hline
\end{tabular}

Os artigos de Vieira ${ }^{27}$ e $\operatorname{Santos}^{28}$ se entrelaçam ao discutirem a capoeira no contexto social e seus significados para a cultura brasileira, bem como a valorização dos movimentos, da musicalidade, do ritmo que estão pautados na forma de jogar e nas características peculiares dessa luta. A capoeira é vista também como uma prática corporal sendo considerada luta e jogo. O texto de Viera ${ }^{27}$ foi o primeiro publicado na RBCE sobre a temática diversidade racial, fazendo crítica sobre a cultura popular no que se refere ao contexto teórico dos livros da literatura fundamentados na teoria nacionalistas, enfatizando a desvalorização da cultura afro-brasileira. A crítica está na perda das características própria da capoeira que é vista apenas como um jogo, desta forma, perde-se sua essência. ${ }^{27}$

$\operatorname{Santos}^{28}$ discute elementos significativos da capoeira na prática social de origem afrobrasileira, remetendo a reflexões de autores/as que abordam questões relacionadas à cultura, linguagem e significados. Stoz e Falcão ${ }^{29}$ investigam a existência de outras lutas e artes marciais praticadas ao som de música, apontando, dessa forma, semelhanças gestuais com a capoeira. Contudo, concluem que a capoeira é a única luta praticada ao som de instrumentos musicais e cântico.

Silva e Ferreira ${ }^{30}$ discutem acerca do corpo e suas implicações na capoeira na área da Educação Física. Busca-se relacionar a ideia da capoeira como jogo da dialogia corporal no âmbito social e sua prática esportivizada. Os autores realizaram uma sucinta analogia sobre o corpo e a capoeira discutindo seus significados como forma de expressão da manifestação cultural. Concluem suas reflexões observando que devemos mudar o nosso olhar sobre os seres humanos, pois, o corpo expressa aquilo que queremos transmitir como uma forma de libertação do que realmente se quer mostrar.

Conexões: revista da Faculdade de Educação Física da UNICAMP, Campinas, v. 13, n. 1, p. 129-161, jan./mar. 2015. ISSN: $1983-9030$ 


\section{CAPOEIRA E ESPORTE}

Encontramos em nossa pesquisa um artigo e um resumo que abordam capoeira e esporte. O Quadro 4 detalha essas informações.

Quadro 4: Publicações sobre capoeira e esporte

\begin{tabular}{lc}
\hline \multicolumn{1}{c}{ Artigos/ Autor/a (s) } & Ano \\
\hline $\begin{array}{l}\text { 14- Projeto de extensão: Expansão da capoeira }{ }^{10} / \text { Aline T. Peres, Anselamo A. Mendes e } \\
\text { Luiz S. Santos. }\end{array}$ & 1999 \\
15- Capoeira e Educação Física: uma história que dá jogo... primeiros apontamentos para \\
sobre suas inter-relações/Paula C. C. Silva.
\end{tabular}

Os dois trabalhos enfocam a capoeira como esporte. Estabelecendo inter-relações entre a capoeira e a Educação Física, Silva ${ }^{31}$ argumenta sobre como a capoeira pode ser interpretada como esporte espetáculo ou como prática corporal da cultura brasileira. Utiliza-se dos aspectos tradicionais e modernos dessa modalidade em suas análises.

Santos, Peres e Mendes ${ }^{32}$ descrevem em seu resumo sobre a implantação de polos de capoeira no município de Maringá-PR, de forma que valorize esse esporte/jogo no trato educacional, histórico, corporal, entre outras. Neste contexto a capoeira teria como foco a qualidade de vida para a comunidade, bem como transmitir seus conhecimentos como conteúdo da Educação Física.

\section{CAPOEIRA E IDENTIDADE}

O Quadro 5, apresenta a descrição das publicações que discutem capoeira e identidade.

Quadro 5 - Publicações sobre capoeira e identidade

\begin{tabular}{|c|c|}
\hline Artigo/autor/a (s) & Ano \\
\hline $\begin{array}{l}\text { 16-Discursos identitários da capoeira na Revista Brasileira de Ciências do esporte } \\
\text { (RBCE)/Juliana A. Almeida e Otávio Taváres. }\end{array}$ & 2008 \\
\hline $\begin{array}{l}\text { 17-A reflexividade nos discursos identitários da capoeira/Juliana A. Almeida, Otávio } \\
\text { Taváres e Antônio J. G. Soares. }\end{array}$ & 2012 \\
\hline
\end{tabular}

Os artigos do Quadro 5 correlacionam-se ao abordarem a capoeira como identidade racial no âmbito social. Almeida e Tavares ${ }^{33}$ apresentam um levantamento bibliográfico de publicações na RBCE entre 1979 a 2006 de pesquisas com o enfoque no tema

\footnotetext{
${ }^{12}$ Trata-se de um resumo publicado na RBCE.

Conexões: revista da Faculdade de Educação Física da UNICAMP, Campinas, v. 13, n. 1, p. 129-161, jan./mar. 2015.

ISSN: $1983-9030$
} 
"capoeira", os quais identificam a capoeira como identidade cultural. ${ }^{33}$ Almeida, Tavares e Soares $^{34}$ analisaram as narrativas identitárias da capoeira em diferentes grupos de capoeira identificando que essa modalidade está pautada no processo da modernização, mas sem perder as características das raízes africanas, bem como o étnico e o multicultural.

\section{CAPOEIRA E DEFICIÊNCIA}

A relação capoeira e deficiência foi encontrada em um artigo nas publicações da RBCE, como descrito no Quadro 6.

Quadro 6 - Publicações sobre capoeira e deficiência

\begin{tabular}{lc}
\hline \multicolumn{1}{c}{ Artigo/autor/a (s) } & Ano \\
\hline $\begin{array}{l}\text { 18-Capoeira para deficientes visuais: comparação do equilíbrio entre praticantes e não } \\
\text { praticantes de capoeira/Janaína B. Matos e Fábio S. Menezes. }\end{array}$ & 2012 \\
\hline
\end{tabular}

$\mathrm{O}$ artigo de Matos e Menezes ${ }^{35}$ comparam o equilíbrio de pessoas com deficiência visuais praticantes e não praticantes de capoeira. Iniciaram suas discussões ressaltando os benefícios da prática da capoeira para os deficientes visuais. Entretanto, ao se aplicar o teste de Escala de Equilíbrio de Berg - EEB e a Escala Internacional de Eficácia de Quedas - FES-I, constataram que os sujeitos praticantes e não praticantes de capoeira envolvidos na pesquisa não apresentavam diferença significativas em relação ao equilíbrio. ${ }^{35}$ Retomando nossas categorias de análise, descreveremos a segui as categorias diversidade racial e Educação Física escolar.

\section{DIVERSIDADE RACIAL}

Sobre a segunda categoria, Diversidade Racial, quatro artigos foram encontrados, como descritos no Quadro 7:

Conexões: revista da Faculdade de Educação Física da UNICAMP, Campinas, v. 13, n. 1, p. 129-161, jan./mar. 2015. ISSN: 1983-9030 


\section{Quadro 7 - Publicações sobre diversidade racial}

\begin{tabular}{lc}
\hline \multicolumn{1}{c}{ Artigos/autor/ a (s) } & Ano \\
\hline $\begin{array}{l}\text { 19- O pensamento médico higienista e a Educação Física no Brasil: 1850-1930 / Carmem } \\
\text { L. Soares. }\end{array}$ & 1990 \\
$\begin{array}{l}\text { 20- Modernismo, raça e corpo: Fernando de Azevedo e a questão da saúde no Brasil } \\
\text { (1920-1930)/Edivaldo Góis Junior. }\end{array}$ & 2009 \\
$\begin{array}{l}\text { 21- Esboço sobre algumas implicações do futebol e da copa do mundo para o Brasil: } \\
\text { identidade e ritos de autoridade/Fernando G. Bitencourt. }\end{array}$ & 2009 \\
$\begin{array}{l}\text { 22- O elogio ao negro no espaço do futebol: entre a integração pós-escravidão e a } \\
\text { manutenção das hierarquias sociais/Bruno O. L. Abrahão e Antônio J.G. Soares. }\end{array}$ & 2009 \\
\hline
\end{tabular}

O texto de Soares $^{36}$ discute o pensamento médico higienista na Educação Física no Brasil no período de 1850 ao ano de 1930. A Educação Física foi utilizada como instrumento de aprimoramento da saúde física e moral, que estava apoiado nos ideais eugênicos de purificação da raça, estando acoplada ao padrão burguês de um corpo forte, saudável, limpo, ordenado. A Educação Física era vista pela sociedade em formação como uma forma de "cura" ou receita de embranquecimento para acabar com os problemas sociais daquela época.

Góis Junior $^{37}$ descreve a questão da saúde no Brasil e a diversidade racial destacando questões sobre os índios, negros e sertanejos sob o olhar de Fernando de Azevedo. O surgimento da Educação Física e sua relação com a teoria higienista e os princípios de moral e cívica relacionados às epidemias vigentes no século XIX são outros focos de análise.

Bitencourt $^{38}$ e Abrahão e Soares ${ }^{39}$ estão elencados nas representações do preconceito e discriminação racial no esporte e na sociedade. Desta forma, Bitencourt ${ }^{38}$ argumenta sobe as relações entre identidade nacional e esporte, pautando na visão da sociedade sobre as questões raciais dentro do esporte, mais especificamente destacando o futebol caracterizado como identidade brasileira. Neste sentido, $\mathrm{O}$ esporte está configurando no meio social em relação à discriminação e o preconceito racial. ${ }^{38}$ Abrahão e Soares (2009) analisam a questão da ambivalência nas representações da "raça negra" no espaço do futebol brasileiro. A grande questão é que mesmo com o preconceito e

\footnotetext{
${ }^{11}$ Trata-se de um resumo encontrado na RBCE.

Conexões: revista da Faculdade de Educação Física da UNICAMP, Campinas, v. 13, n. 1, p. 129-161, jan./mar. 2015.

ISSN: 1983-9030
} 
discriminação, o negro era visto com bons "olhos" em razão de sua habilidade no futebol, angariando títulos para o Brasil. ${ }^{39}$

\section{EDUCAÇÃO FÍSICA ESCOLAR E DIVERSIDADE RACIAL}

O Quadro 8, apresenta os artigos que enfocam Educação Física escolar e diversidade racial.

Quadro 8 - Publicações sobre Educação física escolar e diversidade racial

\begin{tabular}{lc}
\hline \multicolumn{1}{c}{ Artigos/ Autor/a (s) } & Ano \\
\hline 23- A produção do conhecimento na Educação Física brasileira e a necessidade de diálogos & 2007 \\
com os movimentos da cultura popular brasileira/José Luiz C. Falcão. & \\
24- "Essanegranão!": a prática política-pedagógica de uma professora negra em uma escola & 2008 \\
da rede municipal de Porto Alegre: Estudo de caso/Maíra L. Araújo e Vicente Molina Neto. & \\
25- Linguagem discriminatória e etnométodos de exclusão nas aulas de Educação Física & 2009 \\
escolar/Carlos A. F. Silva e Fabiano P. Devide. & \\
\hline
\end{tabular}

Os trabalhos apresentados no Quadro 8 discutem a diversidade racial na Educação Física escolar ressaltando, Araújo e Molina Neto ${ }^{40}$ e Silva e Devide ${ }^{41}$, em especial, as formas de abordagem no ambiente escolar em que pessoas negras são expostas às mais variadas formas de preconceito, independente da posição ocupada, docente ou discente. Falcão $^{42}$ realiza um levantamento de publicações sobre a relação Educação Física e cultura popular. Os artigos consistem do foco principal desse estudo por se relacionarem a diversidade racial com a Educação Física escolar, portanto, serão melhor detalhados no item que se segue.

\section{DIVERSIDADE RACIAL E EDUCAÇÃO FÍSICA ESCOLARNA RBCE}

Como a diversidade racial e Educação Física escolar consiste no foco central de nossa investigação destacaremos os oito artigos da RBCE (1979-2013) que se dedicam a essa vertente, apresentando uma descrição detalhada de seus objetivos, metodologias e conclusões.

O texto de Mestre $\mathrm{Zulu}^{43}$ teve como objetivo abordar aspectos referentes à capoeira, resgatando os valores, os princípios, o simbolismo e a gestualidade da capoeira. Trata-se de um relato de experiência e pesquisa de revisão bibliográfica. Teoricamente, discute a Conexões: revista da Faculdade de Educação Física da UNICAMP, Campinas, v. 13, n. 1, p. 129-161, jan./mar. 2015. ISSN: $1983-9030$ 
capoeira como patrimônio cultural em suas abordagens da antropologia, sociologia, filosofia, educativa, pedagógica, preparativa, estética e lúdica. O autor relata que, após debates e discussões, em 1986 a capoeira foi inserida na rede pública de ensino do Distrito Federal através da disciplina Educação Física, assim como nos centros de aprendizagem. Neste processo, a capoeira foi compreendida como uma atividade que auxilia na formação na socialização do sujeito, aprimorando o respeito dos valores sócio-culturais.

O estudo de Falcão ${ }^{44}$ objetivou analisar as ideias e ações de alunos/as, professores/as e diretores/as que fizeram parte do projeto de capoeira da Fundação Educacional do Distrito Federal. Trata-se de uma pesquisa qualitativa. Apesar de algumas aproximações entre capoeira e Educação Física, o autor descreve que não foi possível identificar nenhuma predominância da abordagem da Educação Física no programa de capoeira Fundação Educacional do Distrito Federal (FDF). Em suas considerações o autor constatou que o componente lúdico prevalece sendo interpretado como uma conduta de "vadiagem", conhecida desde seu surgimento, mas que torna a prática dessa luta prazerosas e empolgante.

De abordagem qualitativa fundamentado em uma pesquisa de revisão bibliográfica, Falcão $^{45}$ discute o processo de inclusão da capoeira no contexto escolar em que a partir de 1980 o crescimento dessa modalidade foi por intermédio da Educação Física. Primeiramente, o autor nos conta sobre a história da capoeira e como essa modalidade foi ganhando espaço em clubes, academias e instituições educacionais. A partir de 1985, ocorreram discussões sobre a inclusão da capoeira no contexto educacional e do desporto, com isso, em 1987 foi criado o $1^{\circ}$ Programa Nacional de Capoeira, tendo como finalidade respaldar e preservar a memória histórica das diferentes manifestações de capoeira confirmada como autentica manifestação da cultura brasileira. Desta forma, muitos grupos de capoeira que faziam parte desse Programa, pautaram-se nos encontros regionais e nacionais desenvolvidos para continuarem divulgando a capoeira como atividade física e educativa. No sentido mais amplo, as discussões permeiam na tentativa de normatização e organização da capoeira para que sua contribuição seja visível no âmbito educacional e esportivo.

Conexões: revista da Faculdade de Educação Física da UNICAMP, Campinas, v. 13, n. 1, p. 129-161, jan./mar. 2015. ISSN: $1983-9030$ 
Enfocando propostas curriculares e práticas pedagógicas, Castro Junior e Sobrinho ${ }^{46}$ relatam a prática pedagógica enquanto professores de Educação Física da rede pública de ensino de Salvador. Os autores ministraram oficinas de capoeira em duas escolas públicas da mesma cidade. No primeiro momento falam sobre o crescimento da capoeira nas escolas no Estado da Bahia sendo, assim, a escola transmissora de conhecimento e, como tal, capaz de transitar por outros meios que esteja ligada a vida social do/a aluno/a. A escola se tornou reprodutora da exclusão social, com isso, é importante que professores/as valorizem as mais diversas produções das manifestações culturais de um povo, tendo em vista o corpo histórico e social. Assim, o/a professor/a é apontado como um ator fundamental na desconstrução da ideologia dominante que se liga intimamente às desigualdades sociais e raciais. Com isso, a prática pedagógica objetivou:

Fazer dos alunos sujeitos reflexivos na elaboração das ideias; circular por mecanismos que valorizem a sua forma de ser, valorizando todas as dimensões humanas: a razão, a emoção e a intuição; ter como práxis pedagógica a criatividade metodológica para não cair na mesmice de fazer receitas prontas. ${ }^{46: 91}$

Assim, acreditam que o conteúdo da capoeira pode ser abordado de forma que medeie tanto a teoria como a prática, resgatando a cultura afro-brasileira, através das aulas. Como metodologia, estruturaram as aulas/oficinas através da proposta metodológica de Paulo Freire e Vigostky, ${ }^{46}$ o que, por meio dessa prática pedagógica puderam observar que a capoeira auxilia na compreensão de ver o/a outro/a. A realização dessas aulas/oficinas foi um atrativo para os/as alunos/as, de forma que os sentidos e significados da capoeira foram compreendidos de forma positiva. Fomentam, ainda, a importância de resgatar e trabalhar no contexto da Educação Física escolar a capoeira não como esporte, mas como um fator social para auxiliar no processo de ensino aprendizagem, na formação social com o intuito de contribuir para a formação de sujeitos reflexivos e críticos.

Falcão $^{42}$ analisou indicadores sobre as produções científicas específica nos eventos da área de Educação Física acerca das várias especificidades que abrange a essa área de conhecimento, principalmente na área da saúde e esporte de alto rendimento. Metodologicamente, trata-se de uma pesquisa bibliográfica de abordagem qualitativa. $\mathrm{O}$ 
autor discute a importância de trabalhar a cultura popular no âmbito educacional demonstrando várias possibilidades como o samba de roda, jongo, frevo, maculelê, entre outras, que são manifestações da cultura afro-brasileira e popular. Em suas considerações finais afirma que é preciso estabelecer um diálogo com os movimentos culturais, em que a Educação Física se encaixa levando em consideração o processo na produção de conhecimento. Problematiza a questão do espaço da Educação de hoje do entendimento que Educação Física para muitos é aptidão, saúde e que não encontra muitas produções científicas referente à diversidade cultural inserida na Educação Física escolar.

Araújo e Molina Neto ${ }^{40}$ objetivaram entender a prática pedagógica de uma professora negra de Educação Física em uma escola da rede municipal de ensino de Porto Alegre. Trata-se de um estudo etnográfico. Os autores abordam a discriminação e o preconceito sofridos por uma professora de Educação Física durante a sua vida estudantil e profissional, destacando como esses processos refletiam de alguma forma na sua prática docente. Os autores também nos chamam a atenção ao falar sobre o déficit de discutir e inserir essas abordagens no contexto educacional na formação inicial e na formação continuada. Essa publicação é a única que cita a lei 10.639/003.

Silva e Devide ${ }^{41}$ realizaram uma pesquisa quantitativa com alunos/as do Ensino Fundamental de uma escola privada na cidade do Rio de Janeiro-RJ. Refere-se aos processos de manifestação da exclusão nas aulas de Educação Física sob a forma de linguagens preconceituosas e discriminatórias sofridas por estudantes através do uso cotidiano de termos pejorativos e apelidos como "perna de pau", "cabelo duro", "quatro olhos", "veadinho", e outros. Em suas considerações, os autores demonstram que a exclusão ocorre através representações figurativas e discriminatórias entre estudantes, que perpassa por um processo constante e cumulativo, reafirmando um modelo de conhecimento elaborado pelo senso comum pautado em reproduções construídas pela sociedade ao longo do tempo.

Silva $^{47}$ discute a prática pedagógica da Educação Física escolar no Ensino Básico e a importância de trabalhar a cultura negra nas escolas através da capoeira. Esta pesquisa Conexões: revista da Faculdade de Educação Física da UNICAMP, Campinas, v. 13, n. 1, p. 129-161, jan./mar. 2015. ISSN: 1983-9030 
foi resultado da primeira parte do curso de formação continuada de capoeira para docentes em que a pesquisadora atuou como observadora participante. $\mathrm{O}$ curso contou a participação de quinze professores/as, sendo desenvolvidas aulas práticas e teóricas. Por meio dessa aprendizagem, os/as docentes começaram a trabalhar com os/as alunos/as das escolas a capoeira como conteúdo curricular. Em suas considerações sobre o curso, a autora relata que os/as professores/as entendem que ao abordarem essas questões da diversidade racial e cultural as:

Condições sociais de produção na qual o professor encontra-se inserido que vão impulsionar a escolha (ou não) da Capoeira para compor o rol das manifestações da cultura corporal a serem estudadas em suas aulas. Dentre tantos condicionantes, pode-se considerar a estrutura e organização da escola, incluindo espaço físico, gestão, comunidade escolar, alunos, políticas educacionais, etc. ${ }^{47: 90}$

A autora afirma que através das práticas pedagógicas a capoeira como elemento da manifestação cultural pode ser ensinada e aprendida ancorada nas interações da linguagem e expressão corporal. Desta forma, baseia-se no contexto histórico e social, auxiliando, nos diferentes sentidos e significados singulares para o sujeito na sociedade. Assim, o/a professor/a tem o papel de se manifestar e transmitir valores que visem o enfrentamento de preconceitos e discriminações no âmbito escolar. Nesse sentido, os/as alunos/as devem ser incentivados/as a respeitar as características e a identidade de cada pessoa, utilizando-se de estratégias pedagógicas que valorizem a diversidade cultural e as manifestações étnico-raciais. ${ }^{47}$

Nessa perspectiva, Libâneo $^{48}$ enfatiza a importância que a Educação deve dar ao "acolhimento à diversidade social e cultural". Portanto, os/as professores/as devem ser mediadores/as ao abordar essas questões, norteando discussões e instigando os/as discentes a refletirem sobre os preconceitos e a reprodução da discriminação e da intolerância no ambiente escolar.

\section{CONSIDERAÇÕES FINAIS}

Mediante nosso estado da arte sobre a relação diversidade racial e Educação Física na RBCE (1979 a 2013), evidenciou-se que essa temática permeia esse periódico timidamente, constando, no período de trinta e quatro anos de existência da revista, um 
total de vinte cinco publicações que aparecem a partir de dez anos após sua criação. Dentre essas publicações, oito enfocam nosso foco central de investigação, a relação diversidade racial e Educação Física escolar.

A predominância da capoeira foi evidente na descrição das produções envolvendo ou não o contexto escolar, o que ressalta, também, a pouca valorização de outras expressões da cultura negra que apresentam dimensões valiosas para a contextualização da corporeidade na Educação Física. Ao realizarmos a pesquisa encontramos dificuldades em razão de algumas edições da revista constarem no portal da RBCE, mas não estarem disponibilizadas ${ }^{12}$ para consulta e as outras serem cadernos de anais de congresso.

Ao verificarmos se a criação dos PCN e a homologação da Lei 10.639/2003 provocaram indícios de alterações nos aspectos quantitativos e qualitativos da inserção da relação diversidade racial e Educação Física escolar na RBCE, os dados não sugerem essa possibilidade. Entre 1996 a 2001 a revista não apresenta publicações neste contexto, que se refere ao período de lançamento dos PCN e, seu caderno 10, "Pluralidade Cultural". Da mesma forma, essa inscrição legal não é mencionada em nenhuma das publicações. Visualizando o ano de 2003 em que a Lei 10.639 foi homologada, encontramos quatro publicações que a antecedem (1989 a 2002) e outras quatro que a sucedem (2007 a 2011). A Lei 10.639/2003 é citada apenas no artigo de Araújo e Molina Neto $(2008)^{40}$. O quadro 9 ilustra nossa constatação.

Quadro 9 - Relação ano/publicação - diversidade racial e Educação Física escolar na RBCE

\begin{tabular}{cccccccccc}
\hline Ano & $\mathbf{1 9 8 9}$ & $\mathbf{1 9 9 5}$ & PCN & $\mathbf{2 0 0 2}$ & Lei & $\mathbf{2 0 0 7}$ & $\mathbf{2 0 0 8}$ & $\mathbf{2 0 0 9}$ & $\mathbf{2 0 1 1}$ \\
\hline Publicação & Artigo 01 & $\begin{array}{l}\text { Resumo 02 } \\
\text { Artigo 03 }\end{array}$ & $\mathbf{1 9 9 7}$ & Artigo 04 & $\begin{array}{c}\mathbf{1 0 . 6 3 9} \\
\mathbf{2 0 0 3}\end{array}$ & Artigo 23 & Artigo 24 & Artigo 25 & Artigo 05 \\
& & & & & & & \\
\hline
\end{tabular}

Dessa forma, ressaltamos a importância da problemática esboçada na lei 10.639/003, ${ }^{49-}$ ${ }^{50}$ que obriga o ensino de história e cultura afro-brasileira na Educação Básica para a desconstrução de estereótipos dessa imagem étnico-racial tanto na escola como na

\footnotetext{
${ }^{12}$ Almeida e Tavares, em "Discursos identitários da capoeira na Revista Brasileira de Ciências do esporte (RBCE)", encontraram vinte e duas produções referente à capoeira entre 1979 e $2006 .{ }^{37}$ Tentamos encontrar e identificar essas produções, mas, encontramos apenas uma. Essas produções possivelmente encontram-se nas edições não disponibilizadas na página da RBCE.

Conexões: revista da Faculdade de Educação Física da UNICAMP, Campinas, v. 13, n. 1, p. 129-161, jan./mar. 2015.
}

ISSN: 1983-9030 
sociedade. Considerando que essa lei enfatiza essas discussões mais especificamente nas áreas de Educação Artística, Literatura e História Brasileiras; fazemos uma ressalva. Acreditamos que essa seja uma problemática essencial para a Educação Física que teve sua história ligada à eugenia racial e, sobretudo, por ser uma disciplina que enfoca o "corpo" em movimento, portanto, permite-nos pensar a diversidade cultural como expressão corporal e incentivar o respeito às características físicas, sociais, sexuais, bem como às identidades sociais dos sujeitos, utilizando-se de estratégias pedagógicas que valorizem essas manifestações culturais.

Entendemos que o processo educativo se constituiu como um instrumento democrático, em que busca acabar com a desigualdade social, racial, indo a busca de uma igualdade possível, dependendo, no entanto, da forma como essas questões são abordadas, contextualizadas e refletidas nas vivências cotidianas de cada grupo. Concretizar um processo como educativo implica, como aponta Saviani, ${ }^{51}$ na passagem da desigualdade para a igualdade. Mediante as análises apresentadas, afirmamos que a Educação Física escolar deve trabalhar as relações entre "corpo" e raça, pois a história do/a negro/a no Brasil está intimamente ligada com a história da Educação Física.

\section{REFERÊNCIAS}

${ }^{1}$ COLÉGIO BRASILEIRO DE CIÊNCIAS DO ESPORTE. Florianópolis, 2013. Disponível em:<http//www.cbce.org.br>. Acesso em: 28 nov. 2013.

${ }^{2}$ REVISTA BRASILEIRA DE CIÊNCIAS DO ESPORTE. Florianópolis, 2013. Disponível em: <http://rbceonline.org.br/revista/index.php>. Acesso em: 28 nov. 2013.

${ }^{3}$ MAtTos, M. G.; ROSSETTO JUNIOR, A. J.; BLECHER, R. Metodologia da pesquisa em Educação Física: construindo sua monografia, artigos e projetos. 3. ed. São Paulo: Phorte, 2008. 223p.

${ }^{4}$ FERREIRA. N. S. A. As pesquisas denominadas “estado da arte". Educação \& Sociedade. Campinas, ano XXIII, n. 79, p. 257-272, ago. 2002. Disponível em: $<$ http://www.scielo.br/pdf/es/v23n79/10857.pdf>. Acesso em 05 set.13.

Conexões: revista da Faculdade de Educação Física da UNICAMP, Campinas, v. 13, n. 1, p. 129-161, jan./mar. 2015. ISSN: 1983-9030 
${ }^{5}$ TRIVIÑOS, A. N. S. Introdução à pesquisa em ciências sociais: a pesquisa qualitativa em educação. São Paulo: Atlas, 1987.

${ }^{6}$ BRASIL. Ministério da Educação e Cultura. Lei. nº10639 de 9 de janeiro de 2003: que trata das diretrizes Curriculares Nacionais para a Educação das Relações Étnicos Raciais e para o Ensino de História e Cultura Afro-Brasileira e Africana. Brasília, , 2004. p. 36. Disponível em: < http://portal.mec.gov.br/arquivos/pdf/ldb.pdf>. Acesso em: 10 out. 2012.

${ }^{7}$ BRASIL. Ministério da Educação e Cultura. Ministério do Trabalho. Programa Nacional de Direitos Humanos. Gênero e raça: todos pela igualdade de oportunidades, teoria e prática. Brasília, 1998.

${ }^{8}$ SANT'ANA, A. O. História e conceitos básicos sobre o racismo e seus derivados. In: MUNANGA, K. (Org.). Superando o racismo na escola. 2. ed. Brasília: Ministério da Educação, 2005.

${ }^{9}$ GOELLNER, S. V. et. al. Gênero e raça: inclusão no esporte e no lazer. Porto Alegre: Ministério do Esporte; Ed. da UFRGS, 2009.

${ }^{10}$ MUNANGA, K.; GOMES, N. L. A produção cultural e artística dos negros no Brasil. In: Para entender o negro no Brasil de hoje: história, realidades, problema e caminhos. São Paulo: Global, 2006.

${ }^{11}$ BOZI, L. H. M. et al. Educação Física escolar: principais formas de preconceito. Revista Digital. Buenos Aires, ano 12, n. 117, fev. 2008. Disponível em: $<$ http//www.efdeportes.com>. Acesso em: 5 ago. 2010.

${ }^{12}$ SOARES, C. L. et al. Metodologia do ensino de Educação Física. São Paulo: Cortez, 1992.

Conexões: revista da Faculdade de Educação Física da UNICAMP, Campinas, v. 13, n. 1, p. 129-161, jan./mar. 2015. ISSN: $1983-9030$ 
${ }^{13}$ GUIMARÃES, A. A. et al. Educação Física escolar: atitudes e valores. Motriz, Rio Claro, v. 7, n. 1, jun. 2001. Disponível em: <http://www.rc.unesp.br/ib/efisica/motriz/07n1/Guimaraes.pdf>. Acesso em: $15 \mathrm{dez}$. 2010.

${ }^{14}$ MOREIRA, A. J.; SILVA, M. C. P. A lei no 10.639/03 e a Educação Física: memórias e reflexões sobre a educação eugênica nas políticas de formação de professores. Revista Digital, Buenos Aires, ano 15, n. 146, p. 1, julho de 2010. Disponível em: <http://www.efdeportes.com/efd146/a-lei-10639-03-e-a-educacao-fisica-eugenica.htm>. Acesso em: 15 set. 2011.

${ }^{15}$ SOARES, C. L. Educação Física, raízes europeias e Brasil. 5. ed. Campinas: Autores Associados, 2012.

${ }^{16}$ NETTO, A. V. Abordagens pedagógicas em educação física: corpo como objeto e abordagem cultural como conteúdo. Revista Digital, Buenos Aires, p.1, abr. 2008, Disponível em: <http://www.efdeportes.com/>. Acesso em: 02 set. 2010.

${ }^{17}$ RANGEL, I. C. A. Educação Física na educação infantil: notas sobre possibilidade de formação de preconceito étnico-racial. Identificando estilos de ensino em aulas de educação física em segmentos não escolares. Revista Mackenzie de Educação Física e Esporte, Campinas, ano5, n. 1, p. 135-146, 2006. Disponível em: $<$ http//www.editorarevistas.mackenzie.br/índex>. Acesso em: 20 jun. 2013.

${ }^{18}$ BRASIL. Ministério da Educação e do Desporto. Secretaria de Educação Fundamental. Parâmetros Curriculares Nacionais: Educação Física. Brasília, 1997. $130 \mathrm{p}$.

${ }^{19}$ BRASIL. Ministério da Educação e do Desporto. Secretaria de Educação Fundamental. Parâmetros Curriculares Nacionais: pluralidade cultural e orientação sexual. Rio de Janeiro: DP\&A, 1997. v. 10, 140p.

Conexões: revista da Faculdade de Educação Física da UNICAMP, Campinas, v. 13, n. 1, p. 129-161, jan./mar. 2015. ISSN: 1983-9030 
${ }^{20}$ AREIAS, A. O que é capoeira. São Paulo: Brasiliense, 1983.

${ }^{21}$ OLIVEIRA, J. P.; LEAL, L. A. P. Capoeira, identidade e gênero: ensaios sobre a história social da Capoeira no Brasil. Salvador: Edufba, 2009.

${ }^{22}$ SOARES, C. E. L. A negrada instituição: os capoeiras na corte imperial 1850-1890. Rio de Janeiro: Access, 1999.

${ }^{23}$ CASTRO JUNIOR, Capoeira de Angola: olhares e toques cruzados entre historicidade e ancestralidade. Revista Brasileira de Ciências do Esporte, Florianópolis, v. 25, n. 2, p. 143-158, jan. 2004. Disponível em: <http://rbceonline.org.br/revista/index.php/>. Acesso em: 11 nov. 2013.

${ }^{24}$ MWEWA, M.; VAZ, A. F. Corpos, cultura, paradoxos: observações sobre o jogo de capoeira. Revista Brasileira de Ciências do Esporte, Florianópolis, v. 27, n. 2, p. 4558, jan. 2006. Disponível em: <http://rbceonline.org.br/revista/index.php/>. Acesso em: 11 nov. 2013.

${ }^{25}$ FALCÃO, J. L. C. O jogo da capoeira: cultura popular no Brasil. Revista Brasileira de Ciências do Esporte, Florianópolis, v. 18, n.1, p. 60-67, set. 1996.

${ }^{26}$ FALCÃO, J. L. C. O jogo de capoeira em jogo. Revista Brasileira de Ciências do Esporte, Florianópolis, v. 27, n. 2, p. 59-74, jan. 2006. Disponível em: <http://rbceonline.org.br/revista/index.php/>. Acesso em: 11 nov. 2013.

${ }^{27}$ VIEIRA, L. R. Criatividade e clichês no jogo da capoeira: a racionalização do corpo na sociedade contemporânea. Revista Brasileira de Ciências do Esporte, Florianópolis, v. 11, n. 1, p. 58-63, set. 1989. Disponível em: <http://rbceonline.org.br/revista/index.php/>. Acesso em: 11 nov. 2013.

${ }^{28}$ SANTOS, G. O. Alguns sentidos e significados da capoeira, da linguagem corporal, da educação física... Revista Brasileira de Ciências do Esporte, Florianópolis, v. 30, Conexões: revista da Faculdade de Educação Física da UNICAMP, Campinas, v. 13, n. 1, p. 129-161, jan./mar. 2015. ISSN: 1983-9030 
n. 2, p. 123-136, jan. 2009. Disponível em: <http://rbceonline.org.br/revista/index.php/>. Acesso em: 11 nov. 2013.

${ }^{29}$ STOTZ, M. B. N.; FALCÃO, J. L. C. Ritmo \& rebeldia em jogo: só na luta da capoeira se canta e dança? Revista Brasileira de Ciências do Esporte, Florianópolis, v. $34, \quad$ n.1, p. 95-110, jan./mar. 2012. Disponível em: <http://rbceonline.org.br/revista/index.php/>. Acesso em: 11 nov. 2013.

${ }^{30}$ SILVA, L. C. D.; FERREIRA, A. D. Capoeira dialogia: o corpo e o jogo de significados. Revista Brasileira de Ciências do Esporte, Florianópolis, v. 34, n. 2, p. 665-681, jul./set. 2012. Disponível em: <http://rbceonline.org.br/revista/index.php/>. Acesso em: 11 nov. 2013.

${ }^{31}$ SILVA, P. C. C. Capoeira e Educação Física: uma história que dá jogo... primeiros apontamentos sobre suas inter-relações. Revista Brasileira de Ciências do Esporte, Florianópolis, v. 23, n. 1, p. 131-145, set. 2001. Disponível em: <http://rbceonline.org.br/revista/index.php/>. Acesso em: 11 nov. 2013.

${ }^{32}$ SANTOS, E. R.; PERES, A. T.; MENDES, A. A. Projeto de extensão "Expansão da capoeira". Revista Brasileira de Ciências do Esporte, Florianópolis, v. 11, n. 1, p. 143, set. 1999. Disponível em: <http://rbceonline.org.br/revista/index.php/>. Acesso em: 11 nov. 2013.

${ }^{33}$ ALMEIDA, J. A.; TAVARES, O. Discursos identitários da capoeira na revista brasileira de ciências do esporte (RBCE). Revista Brasileira de Ciências do Esporte, Florianópolis, v. 30, n.1, p. 171-185, set. 2008. Disponível em: <http://rbceonline.org.br/revista/index.php/>. Acesso em: 11 nov. 2013.

${ }^{34}$ ALMEIDA, J. A.; TAVARES, O; SOARES. A. J. G. A reflexividade nos discursos identitários da capoeira. Revista Brasileira de Ciências do Esporte, Florianópolis, v. 34, n. 2, p. 375-390, abr.jun. 2012. Disponível em: <http://rbceonline.org.br/revista/index.php/>. Acesso em: 11 nov. 2013.

Conexões: revista da Faculdade de Educação Física da UNICAMP, Campinas, v. 13, n. 1, p. 129-161, jan./mar. 2015. ISSN: 1983-9030 
${ }^{35}$ MATOS, J. B.; MENEZES, F. S. capoeira para deficientes visuais: comparação do equilíbrio entre praticantes e não praticantes de capoeira. Revista Brasileira de Ciências do Esporte, Florianópolis, v. 34, n.1, p. 81-93, jan./mar. 2012. Disponível em: <http://rbceonline.org.br/revista/index.php/>. Acesso em: 11 nov. 2013.

${ }^{36}$ SOARES, C. L. O pensamento médico higienista e a Educação Física no Brasil: 18501930. Revista Brasileira de Ciências do Esporte, Florianópolis, v. 11, n. 2, p. 156, jan. 1990. Disponível em: <http://rbceonline.org.br/revista/index.php/>. Acesso em: 11 nov. 2013.

${ }^{37}$ GÓIS JUNIOR, E. Modernismo, raça e corpo: Fernando de Azevedo e a questão da saúde no Brasil (1920-1930). Revista Brasileira de Ciências do Esporte, Florianópolis, v. 30, n. 2, p. 39-56, jan. 2009. Disponível em: <http://rbceonline.org.br/revista/index.php/>. Acesso em: 11 nov. 2013.

${ }^{38}$ BITENCOURT, F. G. Esboço sobre algumas implicações do futebol e da copa do mundo para o Brasil: identidade e ritos de autoridade. Revista Brasileira de Ciências do Esporte, Florianópolis, v. 30, n. 3, p. 173-189, maio 2009. Disponível em: <http://rbceonline.org.br/revista/index.php/>. Acesso em: 11 nov. 2013.

${ }^{39}$ ABRAHÃO, B. O. L.; SOARES, A. J. G. O elogio ao negro no espaço do futebol: entre a integração pós-escravidão e a manutenção das hierarquias sociais. Revista Brasileira de Ciências do Esporte, Florianópolis, v. 30, n. 2/3, p. 9-23, jan. 2009. Disponível em: <http://rbceonline.org.br/revista/index.php/>. Acesso em: 11 nov. 2013.

${ }^{40}$ ARAÚJO, M. L.; MOLINA NETO, V. “Essanegranão!” a prática política-pedagógica de uma professora negra em uma escola da rede municipal de ensino de porto alegre: um estudo de caso. Revista Brasileira de Ciências do Esporte, Florianópolis, v. 29, n. 2, p. 203-225, jan. 2008. Disponível em: <http://rbceonline.org.br/revista/index.php/>. Acesso em: 11 nov. 2013.

Conexões: revista da Faculdade de Educação Física da UNICAMP, Campinas, v. 13, n. 1, p. 129-161, jan./mar. 2015. ISSN: 1983-9030 
${ }^{41}$ SILVA , C. A. F.; DEVIDE , F. P. Linguagem discriminatória e etnométodos de exclusão nas aulas de educação física escolar. Revista Brasileira de Ciências do Esporte, Florianópolis, v. 30, n. 2/3, p. 181-197, jan. 2009. Disponível em: <http://rbceonline.org.br/revista/index.php/>. Acesso em: 11 nov. 2013.

${ }^{42}$ FALCÃO, J. L. C. A produção do conhecimento na educação física brasileira e a necessidade de diálogos com os movimentos da cultura popular. Revista Brasileira de Ciências do Esporte, Florianópolis, v. 29, n.1, p. 143-161, set. 2007. Disponível em: <http://rbceonline.org.br/revista/index.php/>. Acesso em: 11 nov. 2013.

${ }^{43}$ MESTRE ZULU. Depoimento sobre o ideário Beribazu de capoeira. Revista Brasileira de Ciências do Esporte, Campinas, v. 11, p. 64-68, set. 1989. Disponível em: <http://rbceonline.org.br/revista/index.php/>. Acesso em: 11 nov. 2013.

${ }^{44}$ FALCÃO, J. L. C. A escolarização da "vadiação": a capoeira na Fundação Educacional do Distrito Federal. Revista Brasileira de Ciências do Esporte, Florianópolis, v. 16, n. 2, p. 142, jan. 1995a. Disponível em: <http://rbceonline.org.br/revista/index.php/>. Acesso em: 11 nov. 2013.

${ }^{45}$ FALCÃO, J. L. C. O Processo de escolarização da capoeira no Brasil. Revista Brasileira de Ciências do Esporte, Florianópolis, v. 16, n.3, maio. 1995b. Disponível em: <http://rbceonline.org.br/revista/index.php/>. Acesso em: 11 nov. 2013.

${ }^{46}$ CASTRO JÚNIOR, L. V.; SOBRINHO, J. S. O ensino da capoeira: por uma prática nagô. Revista Brasileira de Ciências do Esporte, Florianópolis, v. 23, n. 2, p. 89-103, jan. 2002. Disponível em: <http://rbceonline.org.br/revista/index.php/>. Acesso em: 11 nov. 2013.

${ }^{47}$ SILVA, P. C. C. Capoeira nas aulas de educação física: alguns apontamentos sobre processos de ensino-aprendizado de professores. Revista Brasileira de Ciências do Esporte, Florianópolis, v. 33, n. 4, p. 889-903, out./dez. 2011. Disponível em: <http://rbceonline.org.br/revista/index.php/>. Acesso em: 11 nov. 2013.

Conexões: revista da Faculdade de Educação Física da UNICAMP, Campinas, v. 13, n. 1, p. 129-161, jan./mar. 2015. ISSN: 1983-9030 
${ }^{48}$ LIBÂNEO, J. C. Didática. São Paulo: Cortez, 1990.

${ }^{49}$ BRASIL. Ministério da Educação. Lei n ${ }^{\circ}$ 9.394, de 20 de dezembro de 1996. Diretrizes e Bases da Educação Nacional. 5. ed. Brasília, 2010. 60p. Disponível em: < http://portal.mec.gov.br/arquivos/pdf/ldb.pdf>. Acesso em: 8 jul. 2011.

${ }^{50}$ BRASIL. Lei 10.639/2003. Altera a Lei $\mathrm{n}^{-0}$ 9.394, de 20 de dezembro de 1996, que estabelece as diretrizes e bases da educação nacional, para incluir no currículo oficial da Rede de Ensino a obrigatoriedade da temática "História e Cultura Afro-Brasileira", e dá outras providências. Diário Oficial [da] República Federativa do Brasil, Brasília, DF, 9 jan. 2003. Seção 1, pt. 1. Disponível em: <www.planalto.gov.br/.../constituição /constituiçao.htm>. Acesso em: 12 abr. 2010.

${ }^{51}$ SAVIANI, D. Escola e democracia: polêmicas do nosso tempo. São Paulo: Cortez, 2000.

Recebido em: 30 abr. 2014 Aceito em: 27 nov. 2014 Contato: leydi_.sales@hotmail.com 